\title{
Trends in the Development of the Local Budget and the Importance of Financial Strategy in Our Country
}

\author{
Primova Nigora Ikrom Kizi
}

\begin{abstract}
The article explores the theoretical foundations for the development of financial strategies for local budgets. The formation of local budgets within the framework of the development trends of the state budget in Uzbekistan is analyzed. Based on the research conducted, scientific conclusions and recommendations were formed.
\end{abstract}

Index Terms - budget policy, local budget, financial strategy, budget rules.

\section{INTRODUCTION}

Ensuring the execution of local budgets and strengthening their financial stability are considered to be an important areas of the financial strategy. Strengthening the financial sustainability of local budgets can be reviewed by the means of two aspects. Firstly, it is characterized by a well-formed income base, and secondly, the achievement of cost stability.

In our opinion, the effective operation of the financial strategy of local budgets largely depends on the financial potential of the region. It requires transfering the existing vertical financial authority into a horizontal feature. Failure to comply with this situation in the abstract foreshadows the prospects for financial independence.

In general, financial independence is an important factor in the formation of the financial strategy of local budgets.

In this regard, the stability of local budgets in the implementation of expenditures is explained by the presence of powers in the independent formation of a financial strategy. In the condition of Uzbekistan, the financial strategy of local budgets is implemented centrally. At the same time, expenditures are determined by a single legal document, and profits are collected centrally and distributed across regions through redistribution.

Now we will try to analyze scientific approaches to local budget strategies. T. Zyuzina argues that local (municipal) strategy is not an independence, but an independent development. The researcher notes that the solution of the tasks set in local regions can be economically implemented, first of all, by ensuring the independence of financial and budgetary activities. Thus, the strategy in the system of local self-government shows that municipalities arise with the possibility of developing directions of socio-economic development [1].

Published on October 30, 2020.

Primova Nigora Ikrom Kizi, Tashkent state university of economics, Uzbekistan.

(corresponding e-mail: nigora.primova93@mail.ru)

\section{LITERATURE REVIEW}

Associate Professor N. Korotina offers an analytical methodology for assessing the financial condition of local budgets. In her opinion, the indicators are divided into five groups [2]:

- indicators of a balanced local budget;

- indicators of the financial independence of the municipal structure;

-indicators characterizing the directions of the municipal budgetary policy in the sphere of budget expenditures;

- indicators of budgetary sustainability of the municipal structure;

- indicators of debt of the municipal structure.

The views of the abovementioned Russian scientists try to reflect the factors forming the fundamental basis in the formation of the financial strategy of the local budget. In particular, the transfer of financial authority from vertical to horizontal indicates the need to implement the importance of decentralization.

Therefore, it is advisable to pay attention to some of the scientific findings of Uzbek scientists.

Professor A. Burkhanov and Associate professor. H. Kurbanov substantiate their scientific conclusions aimed at expanding the sources of income for local budgets in the regions. They conduct their research on the example of the Kashkadarya region. As a result, the following scientific conclusions were made [3]: first, the share of economically developed regions in the state budget revenues of the Kashkadarya region is relatively high. Secondly, during the analyzed period, in some districts of the Kashkadarya region, the development of the regional economy is observed, that is, the rapid development of small business and private entrepreneurship, the creation of new enterprises through the further development of investment activities, the financial recovery of economically poor enterprises, the reduction of the existing tax debt, as well as a result of number of reforms due to the transfer of entities operating in the informal sector to the formal sector.

A. Mamanazarov conducted the research aimed at increasing the role of taxes in stabilizing local budgets [4]. In his opinion, the stability of the budget is determined by two aspects. Firstly, it means that the budget must be balanced and should not have a deficit; secondly, it means that it must be kept at the same rate even if there is a deficit.

Z. Ruziev carried out a reserach on the formation of local budget revenues, studying the problems on the scale of Kashkadarya, as well as systematizing them as follows [5]: first, the low level of tax collection in the formation of local budget revenues and incomplete state registration of taxpayers. Secondly, in the structure of local finance, the finance of local budgets and enterprises is being formed, while accounts receivable and payable are going to be grow 
from year to year. It is noted that local enterprises are not focused on creating added value, and, fourthly, they are aimed at setting the rates for deductions from state tax revenues and the allocation of subsidies to local budgets.

It is possible to point out a number of studies on the directions of local budget revenues and their features. Associate Professor A. Khayriddinov formed scientific conclusions aimed at increasing the role and importance of taxes in ensuring the sustainability of local budgets [6]. The indicators of financial stability of local budgets have been systematized. Including: a) their equal income is ensured at the level of expenses of local budgets; b) the indicator characterizing the level of revenues of local budgets, taking into account revenues transferred from the republican budget to the revenues of local budgets; c) the indicator of timely and complete financing of local budgets in the established amounts; d) the indicator showing that the established amounts of revenues recognized as the revenue bases of local budgets, and their timely receipt comprehensively to the budget; e) the indicator characterized by the share of revenues fixed in the structure of total revenues of local budgets; f) the indicator characterized by the share of regulated revenues in the structure of total revenues of local budgets; g) the indicator of targeted subventions of local budgets; g) the indicator characterized by the level of covering part of the local budget expenditures at the expense of subsidies.

In order to solve the problems of the formation of the revenue part of local budgets, Sh. Kiyosov recommends that differentiated revenues should be provided to local governments in the form of the following powers [7]:

- balancing taxes in the regions and coordinating budget needs;

-setting of differentiated tax regimes to ensure investment and activity of employment markets;

- updating and systematizing the subordination of the upper and lower divisions to each other;

- setting tax rates for the use of natural resources in order to develop entrepreneurial activity in the region;

- determination of priority areas of preferential taxation.

H. Kobulov conducted the research on regional opportunities and financial possibilities of local budgets and formed scientific conclusions [8]. He considers that, the description of the financial capabilities of local budgets should not be limited to the revenue base, but should be coordinated with specific measures in the system of additional government measures in accordance with the growth rate of obligations. In other words, "the financial potential of local budgets is a revenue base that allows for the growth of the dynamics of their spending, as well as the fulfillment of budgetary rated formed in accordance with international standards."

In general, scientists have also justified that financial independence depends on two factors of the financial strategy of local budgets. Particularly, these are budget revenues and expenditures. Consequently, balancing them remains the main goal of the financial strategy.

In the above scientific findings, it can be seen the clear approaches to budget revenues parts in the local budget strategies. The scientific conclusions studied by of our scientists are focused on aspects such as balancing budget revenues and tax collection. Scientific conclusions for the account of the absence of a deficit in local budgets are also observed. From our point of view, we believe that a great attention is paid on the absence of deficits in local budgets, which will contribute to maintain a centralized financial strategy.

\section{ANALYSIS AND RESULTS}

Since local budgets are part of the state budget, it is necessary to analyze all the processes taking place in the state budget at formulating their financial strategy. Because local budgets are closely related to the state budget, in particular to the republican budget, the main indicators of which are formed on the basis of structural components and changes in this budget.

State trust funds are also important in developing a local budget financial strategy, whereby spending is directed to areas where local budgets are spent. The issue of the compatibility of these expenditures with the expenditures of local budgets and their necessity for the region is the most urgent part of the financial strategy of local budgets. This is due to the fact that today, funds are directed to the districts to which local budgets come from a variety of sources, including funds and programs, as well as among them there are those whose goals and directions are closely related to the expenditures of local budgets. It justifies the need to develop a document reflecting the financial strategy of local budgets, that is, the most appropriate methods and directions for the use of resources through the accumulation of all public funds allocated to the areas for which the local budget is spent, and the mutual comparison of their goals.

TABLE 1: INFORMATION ON THE SHARE AND STRUCTURE OF THE STATE BUDGET AND STATE TRUST FUNDS IN OUR COUNTRY [9] (IN BILLION SOUMS)

\begin{tabular}{lccccc}
\hline \multirow{2}{*}{\multicolumn{1}{c}{ Indicators }} & \multicolumn{5}{c}{ Years } \\
\cline { 2 - 6 } & 2015 & 2016 & 2017 & 2018 & 2019 \\
\hline I. Gross domestic & 210 & 242 & 302 & 406 & 511 \\
pruduct (GDP) & 183,1 & 495,5 & 536,8 & 648,5 & 838,1 \\
II. Total budget & 53 & 60 & 73 & 111 & 131 \\
revenues, including: & 284,3 & 541,6 & 610,3 & 386,2 & 367,8 \\
State budget & 36 & 41 & 49 & 79 & 112 \\
revenues & 493,2 & 043,4 & 681,0 & 099,1 & 165,4 \\
Revenues of state & 16 & 19 & 23 & 32 & 19 \\
trust funds & 791,1 & 498,2 & 929,3 & 287,1 & 202,4 \\
III. Total budget & 53 & 60 & 71 & 109 & 145 \\
expenditures, & 417,3 & 236,4 & 477,1 & 260,1 & 516,7 \\
including: & 36 & 40 & 49 & 79 & 118 \\
State budget & 257,3 & 911,2 & 343,7 & 736,1 & 008,6 \\
expenditures & 17 & 19 & 22 & 29 & 27 \\
Expenditures of & 160,0 & 325,2 & 133,4 & 524,0 & 508,1 \\
state trust funds & & & & & \\
\hline
\end{tabular}

Analyzing the data of the table, we see that in 2015-2019 the revenues and expenditures of the state budget and the budget of state trust funds have the same constant and sharp growth rate as the gross domestic product. This is especially noticeable in the last three years (2017, 2018 and 2019). Obviously, GDP growth plays an important role. At the same time, the radical reforms carried out in our economy in recent years also require an increase in state budget expenditures. In addition, in our opinion, according to the 
data in the table, the following analytical conclusions can be drawn:

- total budget revenues in 2019 increased by almost 2.5 times compared to 2015 , mainly due to the state budget revenues. Because the revenues of the state budget have increased by 3 times during these years, while the revenues of state trust funds have increased accordingly by only 1.1 times.

- total budget expenditures in 2019 increased by 272 percent compared to 2015, and this is mainly due to state budget expenditures. Since the state budget expenditures in 2019 amounted to 118.0 trillion soums, an increase of 325 percent compared to 2015 (36.2 trillion soums), while the expenditures of state trust funds increased by 160.0 percent, respectively;

- the fact that total expenditures increased more than total revenues indicates a budget deficit. This is reflected in the state budget and state trust funds;

- while government trust fund revenues rose sharply between 2016 and 2018 (190 percent in 2018 compared to 2015), they decreased by 40 percent in 2019 compared to 2018. As a reason, we can cite the fact that the revenues of many state trust funds are included in the state budget;

- expenditures of state trust funds have decreased less compared to revenues, and this is due to the fact that they should be allocated from the state budget in order to cover expenditures. These funds are mainly allocated to the pension fund;

These conclusions are very important in the development of financial strategies of local budgets, the revenues of the state budget and state trust funds as a whole are formed in the territories of local budgets, as well as expenses are also directly implemented in these territories. In this regard, changes in their amounts and ratios, ultimately, will not affect local budgets, and this will serve as the strongest argument in the financial strategy of local budgets, as well as a "guiding beacon", if it is possible to say.

The participation of the state budget and the share of budget revenues of state trust funds in the redistribution of GDP is also important, and its changes are also key factors in the financial strategy of local budgets (Fig. 1).

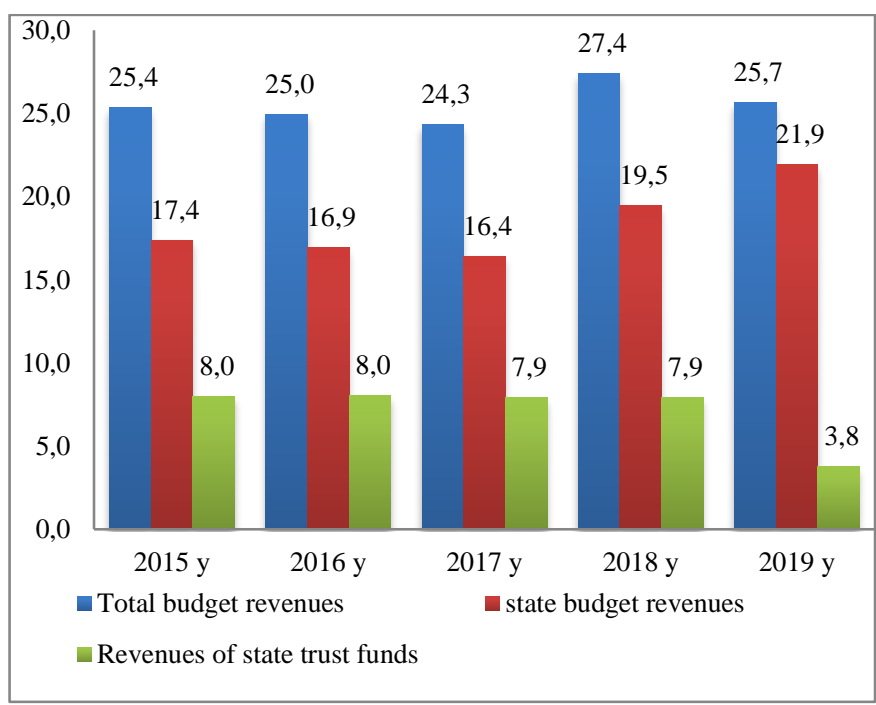

Fig. 1. Share of budget revenues in relation to the gross domestic product (in percent) ${ }^{2}$

During 2015-2019, the share of budget revenues due to the gross domestic product reached 27.4 percent in 2018 alone, while in other years it remained at the level of 24-25 percent. Ultimately, it shows that budget revenues are mainly provided by the growth of the gross domestic product. However, analyzing it structurally, we can identify all the factors. In addition, the figure shows the share of state budget revenues and state trust funds in relation to the gross domestic product, according to which the share of state budget revenues increases and, conversely, the share of state trust funds decreases proportionally. In 2018 alone, it changed slightly, that is, the share of budget revenues increased sharply, although the share of revenues of state trust funds did not change (7.9 percent). From this we can conclude that the growth in the share of state budget revenues in GDP in 2018 was mainly due to the state budget. The main reason for this is that during 2018 there were created many funds included in the state budget, or from this year funds were allocated to previously created funds and many programs were implemented.

Examples of these funds are the Public Relations Fund under the Ministry of Employment and Labor Relations of the Republic of Uzbekistan, "the Future of Youth" Fund under the Youth Union of Uzbekistan, the Public Fund for the support of women and the family, "El-Yurt Umidi" Fund for training specialists abroad and dialogue with compatriots under the Cabinet of Ministers of the Republic of Uzbekistan, the Emergency Medical Care Development Fund under the Ministry of Health of the Republic of Uzbekistan. From 2020, most of these funds will be included in the structure of state trust funds. The programs include such government programs as "Obod kishlok" and "Obod mahalla".

By 2019, the share of state budget revenues over the past five years reached a peak comprising 21.9 percent, while state trust fund revenues bottomed out making 3.8 percent. The main reasons for this, as mentioned above, are the inclusion of many state trust funds in the state budget, as well as the allocation of transfers from the state budget to the Pension Fund.

In general, all of the above information serves as the basis for developing a financial strategy for the local budget. Along with this, we received conclusions and information on the total budget based on the above analysis, which shows the directions of decisions of higher state bodies, including local budgets, which should be taken into account in the financial strategy of local budgets, which are an integral part of all budgets.

\section{CONCLUSION}

Based on the conducted research, we consider it important to pay attention to the following aspects at allocating local budget expenditures:

- introduction of cluster analysis or hierarchical practice in determining the priorities of budget expenditures; 
- development of transparency ratios in the formation of budgetary expenditures and acceleration of ensuring citizen participation;

- determination of the effectiveness of budget expenditures and their systematization, taking into account the characteristics of the region;

- implementation of a system for accounting for budgetary potential in the formation of budget expenditures. At the same time, it is advisable to delegate the authority to make changes in expenditures to the regions.

One of the main problems in the formation of financial strategies for local budgets in Uzbekistan is the existence of the practice of centralized management of budgetary policy. Obviosly, the application of this experience may not have a significant impact on macroeconomic stability. In our opinion, ensuring the territorial financial independence of Uzbekistan in the course of reforms aimed at developing market relations will contribute to bring economic development to a new level. This requires a revision of the territorial financial authority.

We believe that the aspect that should be considered in the horizontalization of financial authority which is advisable to designate the lower and upper boundaries. At the same time, it is important to determine the corridor in comparison with territorial economic indicators at making financial decisions by territorial structures. For example, it is necessary to establish certain percentages in relation to the gross regional product in the implementation of budgetary expenditures. For example, at financing the construction of social facilities, it is understood that the share of budgetary expenditures is set as a percentage. Also, considering the economic specialization of the region, the priority task will be to provide more funds for the development of this area and the practice of its financial support.

\section{REFERENCES}

[1] Zyuzina T.E. Municipal reform and development of the economic basis of local self-government // Sovremennoye pravo. -M., 2015, №2, - p.45-50. J. U. Duncombe, "Infrared navigation-Part I: An assessment of feasibility," IEEE Trans. Electron Devices, vol. ED-11, pp. 34-39, Jan. 1959.

[2] Korotina N.Yu. Methodology for analyzing the financial condition of the budgets of municipalities // Accounting in budgetary and nonprofit organizations. - M.,2014. - №17(353). - p.17-28.

[3] Burhanov A.Yu., Kurbonov H.A. Ways to expand the sources of income for local budgets in the regions (on the example of the Kashkadarya region) // Scientific electronic journal "Economics and innovative technologies". No. 1, January-February 2018.

[4] Mamanazarov A.B. Issues of increasing the role of taxes in stabilizing local budgets: Abstract of dissertation for obtaining Ph.D.degree. - T.: BFA. 2002.- 22 p.

[5] Ruziev Z.I. Enhancement the efficiency of the formation and use of local budget revenues: Abstract of dissertation for obtaining Ph.D.degree. - T.: BFA. 2011. - 22 p.

[6] Khairiddinov A.B. Ways to ensure the stability of the revenue base of local budgets: Abstract of dissertation for obtaining Ph.D.degree. - T.: BFA. 2011 .- 22 p.

[7] Sh. Kiyosov. Problems of formation of local budget revenues // Financial journal. -T.: 2014. -№1. - p. 36-40.

[8] Kobulov H.A. Directions for building the potential of the regional economy and local budgets. - T.: BFA. 2011.- 22 p. 